\title{
PENGEMBANGAN POLA PEMBELAJARAN AGAMA BERBASIS HUMANIS DI MADRASAH
}

\section{Sulalah}

Ketua Jurusan PGMI dan Dosen pada prodi PAI dan PGMI

\begin{abstract}
Members of a religious community have naturally strereotypical opinion about those of religious communities. It is a universal thing in the interaction amongst religions of the education people, with complexity gap from the past up to now not yet filled by strategic concepts in an attempt to buil, mutual respect, harmony, and human ringh. Through his analytic study, the writer highlights' the needs for the govermments to strengthen the religious followers integration through the programs of the humanity education in Indonesia.
\end{abstract}

Keyword: Religious Community, Humanism, Teaching

\section{A. Pendahuluan}

Pendidikan di semua Negara selalu menjadi pondasi bagi segala aspek yang mempengaruhi kemajuan sebuah bangsa. Aspek ekonomi, politik, sosial dan budaya mau tidak mau ditentukan secara prinsipil dari bagimana Negara mengelola bidang pendidikan mulai dari tingkat dasar sampai tingkat tinggi. Pemikiran terhadap upaya peningkatan mutu pendidikan yang menyoroti dari praksis pendidikannya tidak sebanyak membahas secara falsafi dan paradigma pendidikan dipelbagai forum, akan tetapi dampaknya dirasa tidak menjangkau pada berhasilnya maksud dan tujuan itu. Adalah suatu kenyaataan bahwa pendidikan kita sekarang ini tidak untuk memberikan layanan kepada kepentingan siswa, akan tetapi sebaliknya siswa dipaksa untuk memenuhi kepentingan penyelenggara pendidikan dalam meraih penilaian terhadap penyelenggara pendidikan itu. Maka persoalannya adalah mengarah kepada apakah orientasi pendidikan kita tidak lebih mengarah pada perubahan orientasi yang terkait dengan pemikiran terhadap hal-hal berikut; (1) baiknya penyelenggara pendidikan yang lebih mencermati klinik pendidikan, (2) dirasakannya makna transformatif dari proses pembelajaran siswa, (3) dirasa nyamannya proses belajar bagi siswa. Sehinnga beberapa hal yang layak didiskusikan untuk mendekati pemecahan masalah itu antara lain adalah:

1. Indikator mutu pendidikan

2. Penyelenggara pendidikan

3. Pola pembelajaran yang tepat

4. Pendidikan yang nyaman 
Akhir-akhir ini di negara kita, banyak ditemukan pelanggaranpelanggaran bertubi-tubi yang mengarah pada krisis kemanusiaan yang teraktualisasikan lewat isu-isu "SARA" khususnya menyangkut perbedaan agama, mulai dari perkelahian antar pelajar, sampai pada pembakaran tempat-tempat ibadah. yang para pelajar dibawah umur ikut terlibat didalamnya. Ironisnya, para pelaku pelanggaran itu tidak saja dilakukan pelajar usia dewasa (mahasiswa) tapi juga anak-para pelajar dibawah umur yang masuk katagori tingkat remaja. Kecendrungan masyarakat dalam menyelesaikan masalah dengan cara-cara kekerasan, sadis, dan tindakantindakan anarkhis, seperti melakukan pengerusakan, penjarahan, pencurian, perkosaan, menunjukkan penghargaan terhadap hak hidup dan kehidupan sesama manusia berada pada taraf memprihatinkan.

Realitas di atas minimal mengindikasikan adanya dua hal. Pertama, mutu pendidikan kurang berkualitas khususnya pembelajaran agama, kedua, betapa masih rendahnya pemahaman para pelajar tentang nilai kemanusiaan ketika menghargai hak hidup seseorang, sehingga bangsa yang dulu dikenal sebagai masyarakat yang santun, ramah, beradab, menjungjung tinggi harkat dan martabat kemanusiaan, kini patut dipertanyakan ulang. Maka tidaklah salah sepenuhnya ketika muncul suatu kecaman pedas terhadap bangsa Indonesia dengan memberikan julukan sebagai "bangsa sadis/bangsa liar".

Di sisi lain, akhir-akhir ini dunia pendidikan disibukkan oleh serangkaian kebijakan pemerintah seiring dengan perubahan kebijakan nasional secara makro. Istilah-istilah yang muncul untuk memberikan predikat terhadap kebijakan-kebijakan baru tersebut antara lain; Otonomi Pendidikan, Menejemen Berbasis Sekolah (MBS) atau Menejemen Peningkatan Mutu Berbasis Sekolah (MPMBS), Life Skill, dan Kurikulum Berbasis Kompetensi (KBK), dan issue terbaru tentang munculnya reaksi pro kontra dari kalangan masyarakat dari berbagai lapisan menjelang diterapkannya RUU Sisdiknas pasal 13 Tahun 2003.

Serangkaian kebijakan pemerintah di satu sisi merupakan wujud dari kometmen pemerintah untuk terus meningkatkan mutu pendidikan seiring dengan tuntutan dan perkembangan zaman yang semakin mengglobal. Di sisi lain mengundang asumsi tentang ketidak berdayaan penyelenggaraan pendidikan dalam merespon perkembangan globalisasi. Ada indikasi yang menyiratkan betapa Negara hanya setengah hati mengurusi bidang yang cukup krusial ini. Indikasi ini paling tidak terlihat dari ketidakkonsistenan pemerintah menangani berbagi persoalan di bidang pendidikan. Ambillah contoh tentang ujian akhir, kurikulum dan jenjang pendidikan terus menerus berganti tanpa melalui proses evaluasi dan kajian yang mendalam tentang dampak apa yang akan terjadi nantinya. 
Dari sisi filososi, pola pembelajaran pendidikan agama di madrasah belum berhasail merumuskan pendidikan seperti apa yang menjadi model pendidikan di Indonesia. Di tengah kunkungn globalisasi dan modernisasi, pendidikan di Indonesia seperti gagap mengkritisi efek negative dari globalisasi dan modernisasi. Pendidikan agama di madrasah semakin jauh dari cita-cita founding father yang termaktub dalam mukadimah UUD `45 yaitu mencerdaskan kehidupan bangsa.

Apa yang salah dalam penyelenggaraan pendidikan di Indonesia selama ini? Banyak kalangan menilai bahwa pola pembelajaran yang dikembangakan di Indonesia selama ini cenderung lebih mengejar target. Akibatnya tidak jarang peserta didik lebih diposisikan sebagai obyek pendidikan ketimbang sebagai subyek pendidikan, penyelenggaraannya diberlakukan secara general untuk semua daerah baik di tingkat Sekolah Dasar, tingkat Menengah, maupun di tingkat Perguruan Tinggi, sementara desain bersifat sentralistik. Simtem pendidikan semacam ini dapat mengimplikasikan pola pembelajaran yang mengabaikan bahkan boleh dikatakan "menghilangkan" aspek substansial pendidikan khususnya pendidikan agama.

Untuk mewujudkan universalitas pengembangan pola pembelajaran agama yang humanis, tentunya diperlukan usaha keras, yang menjadikan pendidikan berorientasi pada tujuan utamanya yaitu, tranfer of value dan tranfer of methodology, dan bukan sebatas tranfer of knowledge yang dapat mencakup tiga aspek pengetahuan yaitu; aspek kognitif, afektif dan psikomotorik. Dalam hal ini Kaswardi mengidentifikasi kegagalan pendidikan disebabkan empat faktor antara lain; (1) penekanan lebih pada proses tranfer ilmu dari pada proses tranformasi nilai-nilai kepada peserta didik, (2) pelaksanaan pendidikan sebagai bagian penting dalam pendidikan humaniora baru dianggap tidak lebih dari sekedar "pelengkap" atau sebagai hiasan kurikulum. (3) kurangnya penanaman pada sisi nilai (4) kurangnya pehatian untuk menghargai dan mempelajari sesama (Kaswardi: 1993: 48)

Indikasi yang disinyalir oleh Kaswardi tersebut adalah menyangkut sistem pendidikan secara umum, apalagi jika dianalogikan dengan pola pembelajaran agama, tentu akan ditemukan garis demarkasi yang menghubungkan antara pembelajaran agama dengan pemaknaan agama itu sendiri. Oleh sebab itu, perlu pengkajian mendalam terhadap pola pembelajaran yang pada intinya adalah bagaimana pola pembelajrandapat berhasil guna dan berdaya guna sehingga mampu diorientasikan untuk melahirkan lulusan berkualitas yang tidak saja dibekali dengan kompetensi-kompotensi tapi juga memiliki kepekaaan sosial, kepedulian terhadap sesama, dan kesadaran tentang hak-hak asasi manusia (HAM) menuju kesempurnaan sebagai makhluk mulia yang didasarkan atas 
pemenuhan kebutuhan-kebutuhan pokok yang bisa membentuk species manusia.

Bila pendidikan ditinjau dari perspektif individu, maka pendidikan merupakan upaya aktualisasi dan optimalissi potensi dasar yang dimiliki oleh setiap manusia, sedangkan dari perspektif masyarakat pendidikan merupakn proses kulturisasi, yakni sosialisasi nilai-nilai ilmu pengetahuan dan keterampilan yang berkembang dalam masyarakat. Untuk itu secara filosofis dalam mengkaji sebuah pengembangan pendidikan perlu kiranya dikaji dari beberapa aspeknya yang secara garis besar dapat diklasifikasikan ke dalam tiga masalah pokok. Pertama, ontologi, yakni mengenai masalah prinsip-prinsip realitas, meliputi matafisika, alam semesta dan manusia. Kedua, epistimologi, yakni mengenai masalah prinsip-prinsip pengetahuan, meliputi teori kebenaran, teori pengetahuan, dan logika. Ketiga, aksiologi, yakni mengenai masalah prinsip-prinsip nilai, meliputi etika dan estetika (Brameld: 1955: 27). Oleh karena itu, pandangan filsafat mengenai masalah-masalah tersebut akan membawa implikasi bagi sebuah formulasi konsep pendidikan.

Pendidikan Islam sebagai institusi sosial yang bersumber pada ajaran (filsafat) Islam, dengan demikian secara konseptual berkaitan dengan pandangan Islam mengenai metafisika, alam semesta, manusia, pengetahuan, kebenaran, etika dan estetika. Dari beberapa unsur tersebut di atas dalam proses pendidikan, manusia merupakan unsur terpenting, karena manusia merupakan pelaku sekaligus sasaran dari seluruh kegiatan pendidikan (Brameld: 1955: 101), sehingga semua persoalan pendidikan harus dibahas melalui tahapan filosofis yang berhubungan dengan pemahaman secara ontologis tentang manusia, sebab, pandangan filosofis tentang manusia membawa implikasi bagi perumusan tujuan pendidikan, penetapan materi, pemakaian metode dan pendekatan dalam proses belajar mengajar, serta aspek-aspek lain yang berkaitan dengan kegiatan pendidikan.

Dengan kata lain, pandangan filosofis tentang manusia merupakan titik tolak (starting-point) sekaligus menjadi titik tuju/sasaran (ultimate goal) dari seluruh proses pendidikan. Tanpa konsepsi yang jelas tentang manusia proses pendidikan akan berjalan tanpa arah dan orientasi, bahkan dapat dipastikan akan mengalami kegagalan (Salih Abd Allah: 1994: 45). Oleh karena itu, agar praktek pendidikan mengarah pada pola-pola pengembangan dan pembentukan manusia yang lebih "humanis" sesuai dengan kodrat kemanusiaan, maka kajian filosofis yang memberikan acuan konseptual yang tepat tentang manusia menjadi sangat penting.

Konsep pendidikan Islam yang bersumber dari ajaran Islam (alQur`an) dengan demikian berkaitan dengan konsepsi Islam tentang 
manusia. Sementara itu dalam sejarah pemikiran Islam, khususnya dalam diskursus pendidikan, persoalan manusia dapat dikatagorikan kurang mendapat cukup banyak perhatian para pemikir muslim sebab masalah itu terbahas dalam berbagai tempat secara terpencar, seperti dalam figh, teologi, filsafat, dan tasawuf, (Nurcholis Madjid: 1992: 300), sehingga tidak diperoleh suatu konsep manusia yang holistik dan utuh. Untuk mengatasi kepincangan output pendidikan, khususnya di tingkat madrasah, penggalian pengembangan pola pembelajaran yang humanis perlu digali selanjutnya dijadikan sebagai bahan pertimbangan dalam penyelenggaraan pendidikan.

\section{B. Pendekatan Humanistik: Suatu Tinjauan Filosofis}

Konsep humanis dapat digali dengan menggunakan metode content analysis (analisis isi/makna) yang didukung pula dengan pendekatan hermeneutik untuk menggali konsep humanistik dalam al-Quran (Koento Wibisono: 2003). Pendekatan humanistik di sini dimaksudkan bertolak dari ide "memanusiakan manusia". Penciptaan konteks yang akan memberi peluang manusia untuk menjadi lebih humanis, untuk mempertinggi harkat manusia merupakan dasar filosofis, dasar teori, dasar evaluasi dan dasar pengembangan program pendidikan. Dalam hal ini, senada dengan apa yang disinggung oleh Muhaimin bahwa di dalam teori kurikulum terdapat empat pendekatan yang dapat digunakan dalam pengembangan pola pembelajaran yaitu; (1) Pendekatan subyek akademik, (2) Pendekatan humanistik, (3) Pendekatan teknologik, dan (4) Pendekatan rekontruksi sosial (Ali Syari`ati: 1990: 45-49).

Demikian strategis peranan pengembangan pola pembelajaran agama dalam peningkatan kualitas hidup dan kehidupan manusia. Sebagai kerangka dasar oprasional suatu sistem pendidikan, pola pembelajaran sangat menentukan corak dan orientasi hidup dan kehidupan manusia. Sementara itu, formulasi konsep pendidikan banyak dipengarui oleh filsafat suatu bangsa atau masyarakat, sebab di satu sisi pendidikan merupakan manifestasi sekaligus juru bicara dari filsafat setiap bangsa (Djalaluddin: 1996: 13). Sedangkan di sisi yang lain filsafat merupakan teori umum dari pendidikan, landasan dari semua pemikiran tentang pendidikan (John Dewey: 1964: 24). Yaitu suatu pemikiran yang dalam sejarah paradaban manusia telah memainkan peranan penting dalam membentuk prilaku individu dan masyarakat.

Pendidikan Islam menekankan nilai yang dianut peserta didik untuk dipertimbangkan dalam proses pembelajaran, sebab keyakinan agama seseorang dapat mempengaruhi seluruh aspek umat beragama, terutama umat yang memiliki sifat yang kuat, persepsi dan konsepsi hidup yang dipengaruhi oleh keyakian dan ajaran agama. Adalah sebuah keniscayaan manakala pengembangan program pendidikan hanya 
diproyeksikan untuk menghasilakan lulusan yang memiliki kompotensi atau keahlian dan mengabaikan sisi nilai kemanusiaannya.

Pendekatan humanistik dalam kaitannya dengan penyelenggaraan pendidikan dan proses kemajuan manusia merupakan dua unsur yang tak terpisahkan sebagai tujuan utama setiap peradaban yang ingin membangun individu dan manyarakat. Hal itu sejalan dengan sinyalemen Ali Shari'ati yang menyatakan bahwa, beberapa elemen yang berupa pertanyaan seperti; Apakah manusia itu? Harus menjadi apakah dia? Apakah tujuan akhirnya dan apa pula kebutuhan-kebutuhannya? adalah merupakan hal-hal yang harus dipertimbangkan berkenaan dengan pendidikan manusia (Amien Rais: 1994: 63).

Oleh karenanya, penyelenggaraan pendidikan dan proses kemajuan manusia harus ditentukan dan dianalisis sebelum masalahmasalah lainnya dan sebelum dorongan-dorongan yang berkaitan dengan ideologi, filsafat, dan politik. Dengan demikian pendidikan dapat dipahami sebagai instrumen strategi pembangunan manusia yang berkualitas, sekaligus sebagai sistem proyeksi dan rekayasa sosial yang paling efektif untuk menyiapkan suatu model masyarakat "masa depan" yang lebih baik.

Dalam diskursus figh (ilmu hukum Islam) manusia dihadapkan pada Tuhan sebagai Maha Hakim (al-Hakim) sehingga manusia menjadi obyek hukum (mukallaf) yang harus mentaati semua perintah-Nya dan meninggalkan semua larangan-Nya dengan konsekwensi akan mendapat pahala bila ia taat dan akan mendapat siksa bila ia durhaka (Ali Hasaballah: 1964:354-365). Dalam hal ini,'ulama figh secara konsensus telah menetapakan bahwa kriteria seorang mukallaf -orang yang perbuatan-perbuatannya dikenai hukum- adalah orang yang berakal. Dengan demikian dalam konsepsi figh secara formalistis identitas kemanusiaan ditentukan oleh berfungsinya akal manusia.

Teologi Islam (Ilmu al-Kalam) yang menggunakan dalil-dalil rasional untuk memberikan argumentasi atas simpul-simpul keimanan (Ibn Khaldun: 1981: 114), lebih memfokuskan pembahasannya pada kesucian, keagungan dan transendensi Tuhan (al-Ash`ari: 1950: 50) sehingga manusia yang bertawhid dalam konsepsi teologi Islam adalah manusia yang mampu membebaskan diri dari keyakinana-keyakinan yang bersifat material menuju pada etentitas-etentitas rasional murni.

Filsafat Islam dan tasawuf yang menjadikan persoalan Tuhan kebenaran mutlak- sebagai tema sentral, telah banyak mengupas segala sesuatu yang berkaitan dengan manusia dalam hubungannya dengan Tuhan dan segala sesuatu yang ada. Secara umum filsafat dan tasawuf memandang manusia terdiri atas dua substansi; substansi yang bersifat material (Jasmani) dan substansi yang bersifat immaterial (jiwa), 
dengan memandangi substansi immateri sebagai hakikat manusia (Fazlur Rahman: 1979: 95).

Oleh karena itu ketinggian dan kesempurnaan manusia diperoleh dengan menfungsikan substansi immaterial dengan jalan mempertajam daya-daya yang dimiliki.

Bagi filsafat Islam, yang menggunakan istilah al-Nafs untuk menunjuk substansi immaterial manusia, berpikir merupakan daya terpenting dari substansi daya immaterial manusia, sehingga bagi para filosof penajaman daya berpikir supaya dapat berhubungan langsung dengan al-Aql al-Fa'al (akal aktif) sebagai sumber pengetahuan merupakan jalan untuk mencapai kesempurnaan manusia (Taufiq Tawil: 1958: 106) Sedangkan bagi tasawuf, yang menggunakan istilah al-Ruh dan al-Qalb untuk menunjuk substansi immaterial manusia (Abd Raziq alKashani: 1984: 154), daya rasa (al-Zawq) merupakan daya terpenting dari substansi immaterial manusia, sehingga bagi para sufi penajaman daya rasa untuk memperolah pengetahuan tentang hakikat yang tertinggi atau dapat bersatu denganNya (al-Ittihad) merupakan jalan untuk mencapai kesempurnaan manusia (al-Ghazali: 1980: 119). Dengan demikian, bagi para filosof penyempurnaan diri harus melalui proses intelektual (Ibrahim Makdur: 1976: 39) sedangkan bagi para sufi penyempurnaan diri harus melalui proses spiritual-instuisi dan emosi (Hossein Nasr: 1972: 70). Hal ini menunjukkan adanya perbedaan pandang tentang manusia sempurna (insan -kamil) antara para filosuf dan para sufi sebagai akibat perbedaan konsepsi tentang manusia, khususnya tentang daya terpenting substansi immateri manusia.

Perbedaan konsepsi tentang manusia antara pemikir muslim di atas membawa implikasi bagi sistem pendidikan Islam yang dualismedikhotomik. Pada satu pihak, pendidikan Islam berorientasi pada pengembangan potensi intelektual manusia, dan pada pihak lain pendidikan Islam beorientasi pada pengembangan potensi spiritual manusia. Sistem pendidikan Islam yang demikian tentu akan melahirkan output dalam bentuk split personality (kepribadian ganda) yang dikenal dengan sebutan schizophrenia.

Kenyataan di atas tidak sejalan dengan prinsip tawhid dalam Islam, sebab prinsip tawhid tidak hanya berkaitan dengan konsep teologis, tetapi juga berkaitan dengan konsep kosmologis dan antropologis (Ismail Raji al-Faruqi: 1982: 18). Oleh karena itu, untuk memperoleh output pendidikan yang humanis perlu dilakukan penggalian pola pembelajaran dengan pendekatan humanistik sebagai pertimbangan dalam pengembangan kurikulum pendidikan.

Dari uraian di atas dapat dipahami bahwa pembelajaran agama Islam secara konseptual berkaitan dengan pandangan Islam tentang 
masalah-masalah filsafat, seperti alam semesta, manusia, pengetahuan, etika dan estetika. Di antara masalah-masalah tersebut, manusia merupakan masalah pokok dan paling fondamental dalam merumuskan pola pembelajaran agama Islam. Namun, masalah menusia dalam konsepsi Islam berkaitan dengan dimensi intelektual ummat Islam sebagai konsep multi disipliner sehingga masalah tersebut bersifat multi-dimensional, karena memiliki dimensi-dimensi normatif-legalistik, teologis, filosofis, dan mistis.

Oleh karena itu, untuk mendapatkan konsepsi Islam tentang pola pembelajaran yang humanis secara holistik dan utuh, penelitian ini difokuskan pada pola pembelajaran dengan pendekatan humanistikdalam al-Qur`an. Dengan demikian. Persoalan mendasar yang menjadi problema pokok dalam penelitian ini meliputi dua hal; pertama pengkajian terhadap pola pengembangan pembelajaran, kedua analisis konsep humanistik dalam al-Qur`an.

\section{Pola Pembelajaran Berbasis Humanis pada Madrasah Ibtidaiyah}

Madrasah sebagai salah satu representasi lembaga pendidikan Islam yang mempunyai kontribusi penting dalam pengembangan pendidikan nasional. Oleh karena itu, penyelenggaraan pembelajaran di Madrasah memerlukan penanganan yang serius dan sistematis. Kajian ini didasarkan atas pendapat bahwa terdapat berbagai macam pola pembelajaran agama di lembaga pendidikan Islam khususnya di tingkat madrasah yang cenderung lebih mementingkan kepentingan pasar ataupun castumer ketimbang kebutuhan siswa itu sendiri. Fenomena seperti itu dapat dikaji dari perbedaan pola pembelajaran agama terkait dengan kebijakan nasional secara makro tentang pendidikan yang seringkali mengalami perubahan oreintasi dari tahun ke tahun dengan tujuan agar uotput pendidikan dapat senantiasa mampu merespon tuntutan dan tantangan perkembangan globalisasi. Sebagai konsekwensinya, pola pembelajaran dipolarisasikan kearah tersebut, sehingga dapat diprediksi nilai-nilai kemanusia yang lebih mengedepankan kebebasan berkehendak dan berkreasi akan dapat terabaikan. Berdasarkan asumsi ini, jika pola pembelajaran agama didasarkan pada pendekatan humanistik, diharapkan akan dapat mempertajam pola pengembangan pembelajaran agama sekaligus dapat menipis konsep pembelajaran yang tidak relevan dengan konsep humanistic dalam al-Qur`an, sehingga lebih efektif untuk mencapai pada tujuan utamanya yaitu, tranfer ofvalue dan tranfer of methodology, dan bukan sebatas tranfer of knowledge yang hanya lebih menekankan aspek kognitif dan mengabaikan aspek-aspek lainya.

Oleh kerena itu, penelitian tentang pola pengembangan pembelajaran agama yang berbasis humanis menurut konsep humanistik dalam al-Qur`an dipandang penting karena beberapa alasan; 
1. Agar memperoleh pemahaman secara mendalam bahwa sesungguhnya pola-pola pembelajaran yang tampak secara kongkrik dilembaga pendidikan merupakan pantulan dari dunia ide atau dunia makna yang tersembunyi yang dijadikan landasan kebijakan pusat mapun daerah. Bagaimana sesungguhnya para pemegang kebijakan (Depag) memahami atau memberi respon terhadap konsep humanis menurut perspektif al-Qur`an, dalam hal ini pada setting madrarasah Aliyah dalam pengembangan pola pembelajaran agama.

2. Agar menjadi bahan pertimbangan dalam kebijakan-kebijakan pemerintah dalam bidang pendidikan, karena seringkali kebijakan dalam pendidikan baik di tingkat pusat ataupun daeran lebih diorientasikan untuk merespon tuntutan dan tangtangan perkembangan globalisasi. Akibatnya, nilai-nilai kemanusia yang semestinya diinternalisasikan dalam pola pengembangan pembelajaran yang lebih mengedepankan kebebasan berkehendak dan berkreasi jadi terabaikan.

3. Agar hasil penelitian ini dapat diharapkan mempunyai arti kemasyarakatan (social significant) khususnya bagi lembaga pendidikan Islam. Pengetahuan yang komprehensip mengenai konsep humanistik dalam al-Qur`an dan pola pengembangan pembelajaran agama dapat membantu para pelaku pendidikan mulai dari pemegang kebijakan bidang pendidikan sampai pada peserta didik, dalam memperbaiki prilaku beragama sesuai dengan petunjuk al-Qur`an sehingga berguna bagi masyarakat, bangsa, negara, dan agama.

\section{Tujuan dan Manfaat Pola Pembelajarn dengan Pendekatan Humanis}

\section{Dalam Tataran Teori}

Pendekatan humanis ini dioreintasikan untuk memberikan kontribusi yaitu berupa penjelasan yang lebih konkrit operasional berdasarkan data lapangan mengenai konsep humanis perspektif al-Qur’an sebagai pijakan pola pengembangan pembelajaran agama berbasis humanis di madrasah. Selanjutnya, diharapkan dapat memberikan pemahaman komprehensip tentang betapa pentingnya mengkaji konsep humanis dalam al-Quran sehingga dapat mendudukkan secara proporsional perbedaan pandang tentang makna humanis, dan selanjutnya dapat menelorkan teori baru yang terkait dengan pola pembelajaran agama.

\section{Dalam Tataran Praktek}

Konrtibusi pada tataran praktek, bahwa pendekatan humanis diharapkan menjadi bahan pertimbangan dalam menentukan kebijakan-kebijakan pengembangan pendidikan 
khususnya yang terkait dengan pola pengembangan pembelajaran agama. Sejauh pengetahuan penulis, selama ini belum banyak di lingkungan lembaga pendidikan Islam yang secara spesifik mengacu pada konsep humanistik dalam al-Qur`an sebagai paradigma filosofis bagi pola pengembangan pembelajaran agama pada tingkat dasar.

\section{E. Kesimpulan}

Dari hasil tulisan ini dapat disimpulkan, bahwa pendekatan humanistic dalam pembelajaran pendidikan agama dapat digunakan kepada siswa sejak pada tingkat dasar, sebab apa yang dijelaskan dalam alQuran tentang konsep humanistik dapat dilihat dalam realitas sosial. Atau sebaliknya, apa yang terjadi dalam realitas sosial tentang sebuah paradigma humanistik mempunyai landasan filosofi dalam teks-teks alQuran. Hal ini harus menjadi perhatian bagi pemerintahan ke depan, agar kecendrungan pendekatan sumber daya manusia di bidang pendidikan, yang memperlakukan manusia sama dengan obyek mati, bahkan diukur dan diperjualbelikan sebagai komuditi, harus dikaji ulang.

Persoalan filosofi pendidikan di madrasah juga perlu menjadi perhatian yang serius. Pendekatan yang selama ini ini berjalan cenderung tereduksi masalah-masalah teknis pendidikan seperti kurikulum, kepentingan politik dan elit tertentu. Padahal konsep dan rumusan pendidikan agama amat berpengaruh terhadap implementasi, dinamika, arah dan pelaksanaan sebuah proses pendidikan. Pelaksanaan pendidikan agama selama ini lebih terkonsentrasi pada aktifitas guru atau pendidik. Filosofi yang demikian akan menelikung kemampuan kreatifitas peseta didik dan pedagoginya cenderung bersifat naratif dan indoktrinatif. Peserta didik ditempatkan seperti obyek penderita atau gudang yang materi berdasarkankurikulum yang diajarkan. Ruang kreatifitas dan aktualisasi diri peserta didik amat kurang sehingga banyak berkutat pada nyontek atau mengembangkan mtode repetisi bahan-bahan. Karena itu, tujuan pendidikan agama tidak boleh melupakan landasan konseptual filosofi pendidikan yang membrikan kebebasab pada individu (memanusiakan) dan mampu menyiapkan genesari masa depan untuk bisa bertahan hidup survive dan berhasil menghadapi tantangan jamannya.

\section{F. DAFTAR PUSTAKA}

Abd Raziq al-Kashani, Istilahat al-Sufiyah, cet. 2, Kairo: Dar al-Ma'arif, 1984.

al-Faruqi, Ismail Raji, Tawhid: Its Implication for Thought and Life, Kuala Lumpur: The Internasional Institute of Islamic Thought, 1982.

al-Ghazali, Abd Hamid Muhammad Ibn Muhamad, al-Mustashfa Min Ilm al- Usul, Vol. III, Bairut: Dar al-Fikr. t.t..

, Ihya' Ulum al-Din, vol.. 8 Bairut: Darr al-Fikr, 1980. 
Ali Hasaballah, 'Ali, Usul al-Tashri' al-Islamiy, cet. 3, Mesir: Dar al-Ma'rif, 1964.

`Ali Ibn Ismail al-Ash `ari, Abu al-Hasan, Makalat al-Islamiyyin wa al-Ikhtilaf al-Mushallin, Kairo: Maktabah al-Nahzah al-Misriyah, 1950.

al-Shaybani, Umar Muhammad al-Toumi, Filsafat Pendidikan Islam, ter. Hasan langulung, Jakarta: Bulan Bintang, 1979.

al-Naquib al attas, Sayyid Mohammad, Konsep pendidikan Islam: Suatu Rangka Pikir Pembinaan Filsafat Pendidikan Islam, ter. Haidar Baqir, Bandung: Mizan, 1992.

Brameld, Theodora, philoshopies of Education in Cultural Perspactives, New York: Holt Rinehart \& Winston, 1955.

Dewey, John, Democraty and Education: An Introduction to the Philosophy of Education, New York: The Mac Millan Company, 1964.

Fazlur Rahman, Islam, cet. 2, Chicago: The University of Chicago Press, 1979.

Ibn Khaldun, Abd Rahman, Mukaddimah Ibn Khaldun.Bairut: Dar al-Fikr, 1981.

Kaswardi, E.M.K. 1993. Pendidikan Nilai Memasuki Tahun 2000, Jakarta: PT Gramedia, 1993.

Madjid, Nurcholis, Islam Doktrin dan Peradapan: Sebuah Telaah Kritis Tentang Masalah Keimanan, Kemanusiaan, Kemoderenan, cet. 2, Jakarta: Yayasan Waqaf Paramadina, 1992.

Makdur, Ibrahim, Fi Falsafah al-Islamiyah: Manhaj al-Tarbiyah, vol..1, Kairo: Dar al-Ma'arif, 1976.

Nasr, Sayyed Hossein, Sufi Essays, London: George Allan \& Unwin Itd., 1972.

,Islamic Life and Thought, New York: Albani State University Press, 1981.

Salih Abd Allah, abd al-Rahman, Teori-Teori Pendidikan Berdasarkan alQur'an, ter. M. Arifin Jakarta: Reneka Cipta, 1994.

Shari'ati, 'Ali, Tugas Cendekiawan Muslim, ter. Amein Rais, Jakarta: Raja Grafindo Persada, 1994.

Syariati, Ali, Humanisme antara Islam dan Madhab Barat, ter., Afif Muhammad, Jakarta: Pustaka Hidayah, tt.

- Tugas Cendekiawan Muslim, cet. 4, ter. M. Amien Rais, Jakarta: Raja Grafindo Persada, 1994.

Wibisono, Koento, Filsafat Ilmu, materi kuliah Filsafat Ilmu pada program 
Sulalah-Pengembangan Pola Pembelajaran Aga ma Berbasis Humanis Di Madrasah

doktor angkatn ke II Pascasarjana IAIN Surabaya 2003.

Kaswardi, E.M.K. 1993. Pendidikan Nilai Memasuki Tahun 2000, Jakarta: PT Gramedia, 1993.

Makdur, Ibrahim, Fi Falsafah al-Islamiyah: Manhaj al-Tarbiyah, vol..1, Kairo: Dar al-Ma'arif, 1976.

Nasr, Sayyed Hossein, Sufi Essays, London: George Allan \& Unwin Itd., 1972.

Islamic Life and Thought, New York: Albani State University Press, 1981.

Taufiq Tawil, Qissah al-Nisa' Bain al-Din wa al-Falsafah, Kairo: Maktabah alMisriyah, 1958. 